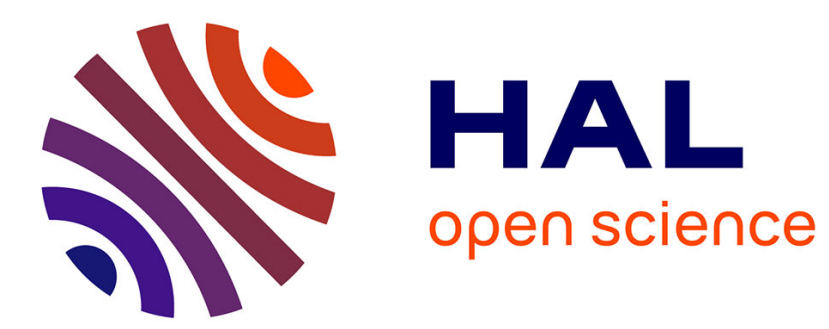

\title{
Employment and decent work in the era of flexicurity
} Robert Boyer

\section{To cite this version:}

Robert Boyer. Employment and decent work in the era of flexicurity. 2006. halshs-00590452

\section{HAL Id: halshs-00590452 \\ https://shs.hal.science/halshs-00590452}

Preprint submitted on 3 May 2011

HAL is a multi-disciplinary open access archive for the deposit and dissemination of scientific research documents, whether they are published or not. The documents may come from teaching and research institutions in France or abroad, or from public or private research centers.
L'archive ouverte pluridisciplinaire HAL, est destinée au dépôt et à la diffusion de documents scientifiques de niveau recherche, publiés ou non, émanant des établissements d'enseignement et de recherche français ou étrangers, des laboratoires publics ou privés. 
Paris-Jourdan Sciences Economiques

48, BD JOURDAN - E.N.S. - 75014 PARIS

TEL. : 33(0) 143136300 - FAX : $33(0) 143136310$

www.pse.ens.fr

WORKING PAPER Nº 2006 - 21

Employment and decent work in

the era of flexicurity

Robert Boyer

JEL Codes : J23, J31, J48, J83, 015

Keywords : Workers security, labour flexibility, decent work, developing countries, labour standards, employment diagnosis, productive employment, welfare, flexicurity 


\title{
EMPLOYMENT AND DECENT WORK IN THE ERA OF FLEXICURITY
}

\author{
Robert Boyer \\ PSE - P aris-jourdan $S_{\text {ciences }} E_{\text {conomiques }}$ \\ (Joint research unit CN R S-E H E SS-E N PC-E N S) \\ 48, Boulevard Jourdan 75014 PARIS, France \\ Phone: (33-1) 43136256 - Fax: (33-1) 43136259 \\ e-mail: robert.boyer@ens.fr \\ web site: http://www.jourdan.ens.fr/ boyer
}

This paper was prepared for the UN/DESA Development Forum on Productive Employment and Decent Work, held at United Nations Headquarters, New York, on 8 and 9 May 2006. 


\title{
EMPLOYMENT AND DECENT WORK IN THE ERA OF FLEXICURITY
}

\author{
Robert Boyer
}

\begin{abstract}
This paper challenges the conventional wisdom that the dynamism of employment is always contradictory to the enforcement of some forms of security for workers. Contemporary theorizing now recognizes the specificity of the wage-labour nexus. Consequently, minimum security is required for good economic performance by firms and national economies. A comparative analysis of OECD countries shows that the extended security promoted by welfare systems has not been detrimental to innovation, growth and job creation. Developing countries cannot immediately catch up with the emerging standards of flexicurity but the methodology of employment diagnosis might help them in designing security/flexibility configurations tailored according to their domestic economic specialization, social values and political choices.
\end{abstract}

\section{EMPLOI ET SÉCURITÉ À L'ÈRE DU MODĖLE DANOIS}

Robert Boyer

\section{Résumé}

Le papier discute la vision traditionnelle en vertu de laquelle la mise en œuvre d'une forme ou une autre de sécurité des travailleurs est partout et toujours défavorable au dynamisme de l'emploi. Les nouvelles théories du travail reconnaissent la spécificité du rapport salarial, de sorte qu'un degré minimum de sécurité s'avère nécessaire pour garantir l'efficacité tant des entreprises que des économies nationales. Une comparaison des pays de l'OCDE montre qu'une sécurité étendue grâce à des systèmes de couverture sociale est loin d'avoir été défavorable à l'innovation, la croissance et la création d'emplois. Les pays en voie de développement ne peuvent pas rattraper immédiatement les normes implicites à la flexicurité danoise mais la méthodologie du diagnostic des facteurs qui limitent l'emploi peut être très utile pour expliciter la configuration des sécurités et flexibilités qui répond à la spécialisation économique, les valeurs et les choix politiques propres à chaque pays.

JEL Classification: J23, J31, J48, J83, O15

Keywords: Workers security, Labour flexibility, Decent work, Developing countries, Labour standards, Employment diagnosis, Productive employment, Welfare, flexicurity

Mots clés: Sécurité des travailleurs, flexibilité du travail, économie en développement, normes internationales de travail, diagnostic d'emploi, couverture sociale, flexicurité. 


\section{EMPLOYMENT AND DECENT WORK IN THE ERA OF FLEXICURITY}

Robert Boyer

CONTEMPORARY ECONOMIC THEORIES: A REAPPRAISAL OF THE LABOUR FLEXIBILITY/ SECURITY DEBATE

THE INADEQUACY OF A PURE, COMPETITIVE MODEL IN ASSESSING THE IMPACT OF A SECURITYENHANCING WELFARE STATE.

THE NEED TO TAKE INTO ACCOUNT THE EXTERNALITIES ASSOCIATED WITH VARIOUS FORMS OF SECURITY

SOME LABOUR SECURITIES PROMOTE ECONOMIC PERFORMANCE. .14

JOB SECURITY HELPS WORKFORCE REDEPLOYMENT.

LABOUR-MARKET POLICIES CAN REDUCE JOB INSECURITY ...................................................................

SMALL, OPEN ECONOMIES HAVE MORE ACTIVE EMPLOYMENT POLICIES ……….......................................17

ACTIVE WELFARE MAY BE COMPLEMENTARY TO INNOVATION POLICY ……………………....................19

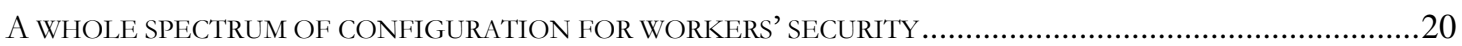

DEVELOPING COUNTRIES: QUITE SPECIFIC CONDITIONS......................................................21

CONSTRAINTS AND OPPORTUNITIES REGARDING PRODUCTIVE EMPLOYMENT AND DECENT WORK..........21

THE AMBIGUOUS IMPACT OF GLOBALIZATION ON LABOUR STANDARDS ..............................................25

EMPLOYMENT DIAGNOSIS: A METHOD FOR DRAWING A DIVIDING LINE BETWEEN FLEXIBILITY AND

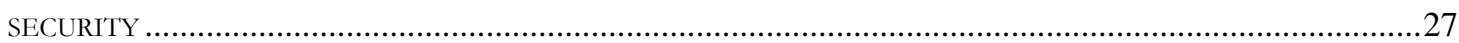

WHAT ARE THE BEST METHODS FOR PROMOTING DECENT WORK? ................................................. 31

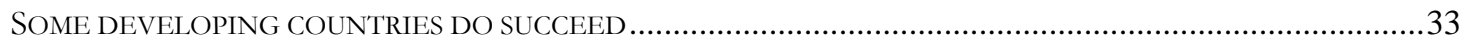

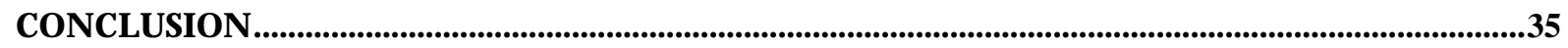

REFEREN CES 


\section{INTRODUCTION}

The current concern about development with decent work has to be appraised in historical retrospect. Back in the 1960s, the so-called Golden Age for developed countries, the institutionalization of workers' rights and the constitution of an extended welfare state proved to be compatible with a fast and rather stable growth. At that time, dynamic efficiency and social justice were more frequently perceived as complementary rather than contradictory.

Since the 1970s, however, the slowdown of growth and the emergence of mass employment have put into question this virtuous configuration. What was thought of as an asset has turned out to be viewed as a liability. In this context, experts have convinced many Governments that most, if not all, labour-market institutions had to be reformed because they generated various rigidities detrimental to job creation and innovation. The strategies of flexibilization of labour markets have been generalized and concern not only wage formation, employment legislation and welfare, but also work organization. During this second epoch, most analysts have perceived a trade-off between economic efficiency and social justice.

The pressure to reform labour contracts and welfare in developed countries has been reinforced by the process of globalization: multinational corporations have delocalized significant segments of the value chain towards emerging countries, especially in Asia. These countries were supposed to enjoy a definite competitive edge, associated with low wages, high labour-market flexibility and, for some of them, fast growth of their domestic markets. Consequently, the relative decline of old industrialized countries was partially attributed to the rigidity of their labour-market institutions, whereas the surge of emerging countries benefited from highly flexible labour markets. Thus, during the 1990s, more and more worker security-enhancing devices have been perceived as detrimental to job creation, growth and innovation. 
The core message of this paper is that this period might be over, for at least three main reasons. First, the old labour-market theory, based on symmetric information, has been replaced by more realistic hypotheses that take into account the specificity of the capital-labour nexus, which is both a market contract and a subordinate relationship. Therefore, low wages and poor working conditions are no more an optimum for firms, given the endogeneity of work intensity, commitment and productivity. For instance, a fair labour contract that warrants a form of security - employment stability, access to unemployment benefits, right to training and further education - might be superior both for firms and individuals compared with a typical competitive adjustment of wages to the ongoing equilibrium value. The paper proposes to detect the various mechanisms according to which security-enhancing welfare may improve simultaneously the financial performance of a firm and the welfare of the workers.

A second line of argument builds upon the results of various comparative analyses of the performance of the member countries of the Organization for Economic Cooperation and Development (OECD) during the last decade. Whereas the countries that had more fully deregulated their labour market were supposed to be the best performers in terms of job creation, innovation and growth, a surprising finding focuses upon the quite remarkable configuration of small social democratic economies (Finland, Denmark and Sweden). Generous income security is associated with the wide freedom granted to firms concerning employment decisions. This exchange of a form of security against the capacity for adjustment is part of a compromise that delivers very good macroeconomic outcomes. Similar to the Golden Age, the security of workers is no longer in contradiction with the flexibility of firms. This flexicurity model is an alternative to the flex-flexibility, typical workfare based upon an absolute search for 
flexibility in all the components of the labour contract (employment, hours, wages, social benefits, unemployment compensation, skills and competence, etc.).

A last reason is specific to developing countries. A decade ago, the implementation of the Washington Consensus was supposed to promote high-speed growth, near full-employment and the progressive eradication of poverty. Nowadays, it is clear that the link between fast growth and the subsequent improvement in labour standards is far from mechanical. Of course, the poverty rate has been significantly reduced in large countries such as China and India, but it is not a widely observed phenomenon. Furthermore, a new branch of development theory stresses that basic rights might well be a precondition for successful growth strategies, and not only the longterm automatic outcome of economic reforms in the direction of efficiency. Similarly, empirical investigations recurrently show that low wages and poor working conditions are not necessarily the key factors governing the localization of multinationals. Consequently, the crucial issue might be expressed in the following manner: what kind of workers' security could benefit development, and how could the required securities be implemented.

The paper builds upon these three lines of analysis in order to detect how the reactivity to macroeconomic shocks, globalization and technical change can be made compatible with the implementation of some securities for the workers of developing countries.

\section{CONTEMPORARY ECONOMIC THEORIES: A REAPPRAISAL OF THE LABOUR FLEXIBILITY/ SECURITY DEBATE}

The issue of decent work, and more generally workers' security, is closely linked to the broader question of the function and the impact of the welfare state. Actually, the literature on the welfare state is split along clear dividing lines. On one side, the theoreticians, especially the economists, tend to refer to a perfectly organized society, with full information and insurance, and compare this ideal with existing welfare states, which of course are highly imperfect. 
Consequently, there is a strong temptation to assert that the existing welfare state is the main cause of unemployment, poverty and social exclusion that should not exist in the pure theory of a market economy governed by democratic principles. On the other side, the specialists of the domain do analyse carefully the inner working of each system, the diversity of the strategies of the actors involved and, finally, the variety of organizations observed all over the world with no clear nor absolute superiority of any single configuration. Roughly speaking, each society finally inherits a welfare state that is coherent with its system of values, political organization and economic specialization.

Actually, few frameworks take into account both the theoretical and empirical size of a welfare system and analyse the long-run impact of social security. By chance, the renewed interest for growth theory and the recent concern for institutional analysis entitles a third way, that this paper tries to follow.

\section{The inadequacy of a pure, competitive model in assessing the impact of a security-enhancing welfare state}

After World War II, the issue of social security used to be analysed within a macroeconomic framework, put forward by the Keynesian breakthrough: in a sense, the Beveridge Plan was conceived as a complement to a full-employment programme. Nowadays, the intellectual scheme governing economic policy decisions is strongly embedded into a microeconomic analysis of the rational choice of agents facing a system of prices, incentives and uncertainties (Council of Economic Advisers, 1998). Thus, implicitly at least, Partial or General Equilibrium Theory is frequently used to assess the impact of the social benefits and collective coverage of risk typical of welfare. If one adopts the old microeconomic theory, where information is perfect and no externality prevails, then ineluctably any welfare system will introduce a distortion departing from a pure and perfect competitive equilibrium that is simultaneously a Pareto optimum. This is specially so if one considers some form of collective 
control over employment or collective coverage of individual risk. Under this framework, any welfare measure is always costly in terms of economic efficiency: this trade-off should be arbitrated by the democratic system, but the economist is clearly on the side of efficiency and efficacy (figure 1).

Figure 1 - Why the competitive equilibrium theory is not suited for assessing the impact of the security brought by welfare systems

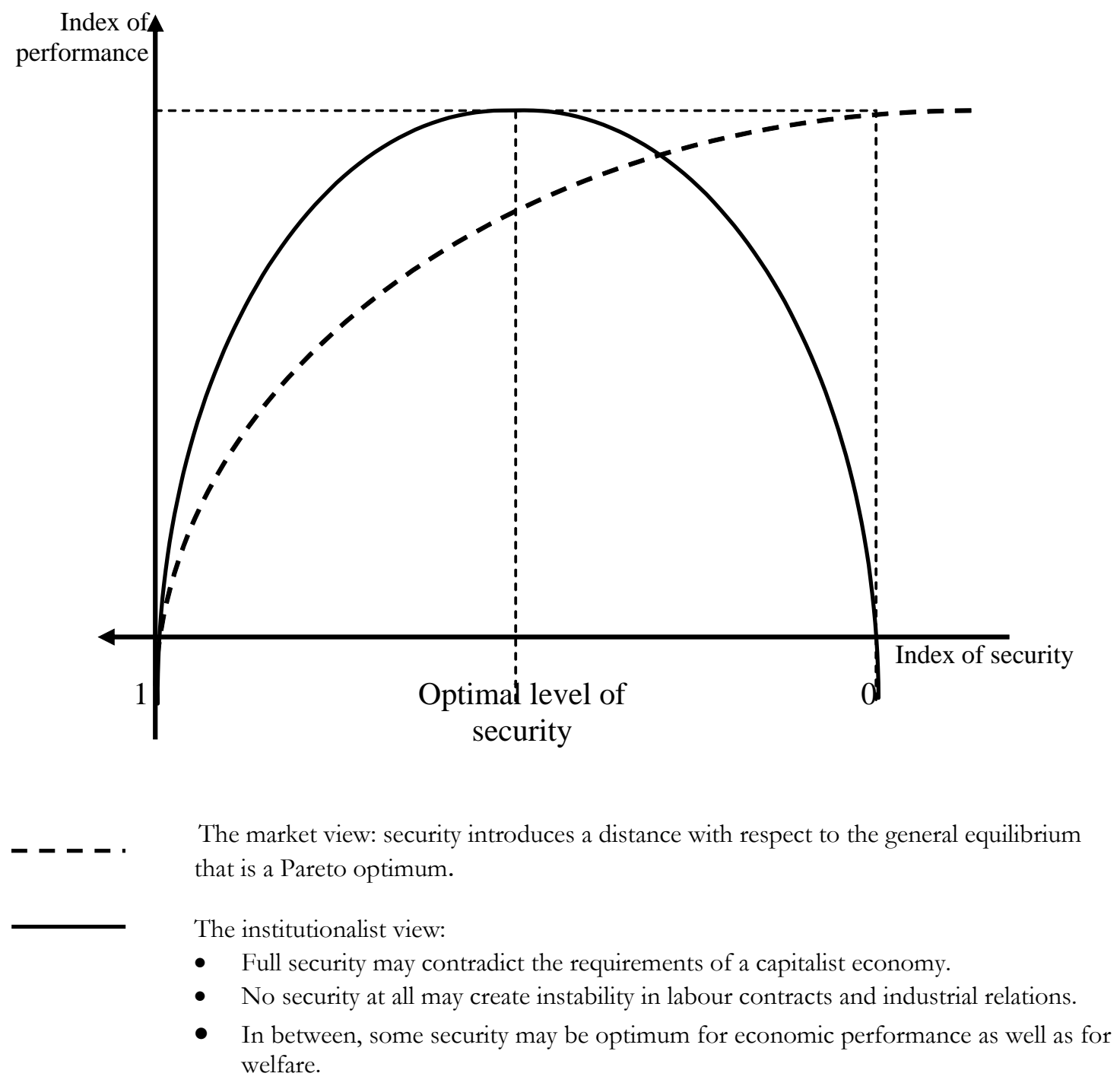

Such an approach is largely unsatisfactory and in some instances erroneous. First of all, modern economic theory does not confirm the generality of the convergence of a "tâtonnement" process toward equilibrium. It has been argued convincingly that the two welfare theorems 
actually relate to a perfectly planned economy and not at all to a fully decentralized market economy (Benassy, 1982). If, then, information is made imperfect and the economy is subjected to stochastic disturbances, it has been proved that a fully rational economic agent who would react instantaneously to the price signals exhibited by the market would be worse off than a prudent agent who had adjusted his strategy smoothly (Heiner, 1988). Of course, not adjusting at all would lead quasi certainly to the bankruptcy of the agent: the maximum speed of adjustment is not optimum any more. This is a first and quite general rationale for the inverse U-shaped performance curve of figure 1.

Many other models suggest a similar result about the optimality of an intermediate level of adjustment and of flexibility. For instance, a very simple multi-sector model describing income distribution and effective demand formation shows that the same inverse U-shaped curve is observed with respect to the speed of adjustment of employment to its (neo-classical) efficient level (Boyer, Mistral 1982). The reason is simple: what is gained at the micro level in terms of productive efficiency can be lost at the aggregate level by a negative impact upon effective demand. More general models inspired by modern classical theory put forward the role of the correction of various disequilibria (on the product market via inventories, on the labour market via hiring, and on the financial market via investment) in the convergence, respectively, towards a short-, medium- and, finally, long-term equilibrium. Nevertheless, if the speed of reaction of the firms is too high, one observes a bifurcation point generating two equilibria. In between, there is the equivalent of a crisis, in the sense of a brusque shift from one equilibrium to another (Dumenil, Lévy, 1993). Again, the maximum speed of adjustment is adverse to the economic performance and even to the existence of a market equilibrium. Such a property is finally very general and concerns too financial markets themselves: up to a threshold, too fast capital mobility in reaction to profit rate differentials may propitiate a period of fast growth and then an abrupt 
crisis. This pattern is explained by the lack of productive diversity to cope with new types of disturbances or stochastic shocks (Eliasson, 1984).

A more specific analysis suggests that there generally exists an inverted U-shaped relation between the degree of security and long-term economic performance (Altman and others, 2006). First, a basic level of security allows individuals to take risks, for instance, to invest in education, launch a business or try new methods or imagine new products, all actions that are at the origin of growth. Second, the existence of a safety net mitigates the adverse effects of hardship because the assistance in terms of finance, education or training helps in overcoming the temporary setbacks that go along with a constantly evolving economy. A third benefit of a modicum of security is especially important during a period of globalization and fast technical change: an adequate level may lessen the demand for protectionism and Malthusian policies that would hamper growth. The very process of creative destruction calls for some form of security for the industries and jobs adversely affected by the restructuring of the economy.

Thus, neither total insecurity nor complete security is good for long-term growth. Consequently, the issue is to find out what the optimum degree and form of security should be, given the parameters of each economy. There is no rationale for seeking maximum flexibility and, conversely, a significant reactivity in the labour market is not necessarily in contradiction with decent work, defined as the right to basic security. These general results are especially important for the assessment of welfare systems because they basically deliver a form of insurance and a smoothing of adverse events. From a theoretical point of view they may (or may not - but this is an empirical issue) contribute to macroeconomic performance. 


\section{The need to take into account the extemalities associated with various forms of security}

The previous reasoning was questioning the hypothesis of full information in an uncertain world and was claiming that a form of insurance and smoothing of disturbances might improve macroeconomic performance. But there is a second justification for extended welfare and public intervention, i.e., the existence of positive or negative externalities that cannot be internalized via private insurance or incentives directed towards the private sector (WHO, 2000: 55). The argument can be developed, made more specific and can closely conform to the various forms of security analysed by the Socio-economic Security Programme (ILO, 2004b) (figure 2).

- Traditionally, public authorities may promote income security in reaction to the adverse outcome of pure market logic upon poverty and social inequalities. One form of this security is the imposition by law of a minimum wage. For this intervention to be effective and binding, conventional micro theory concludes that the less-paid workers will be priced out of the market, provoking then unemployment. It is, however, only a partial-equilibrium result since such a measure has a global impact upon the total wage bill, hence the level of effective demand. Have recent careful studies not concluded that the recent hikes in the American minimum wage have finally benefited employment, contrary to the expectation of a typical neo-classical analysis? This short, medium-term impact might be completed in the long run by the incentive that the absence of a downward flexibility of wage exerts upon the direction and intensity of labour-saving innovations. On aggregate, the impact might be positive -- and has actually been during the Golden Age (Boyer, 2000).

- A second form of income security, the unemployment insurance system, has also some impact upon the speed of adoption of technological and organizational change. Whereas 
most of the analysts focus upon the negative side of the social contribution associated with the payment of unemployment benefits, i.e., less employment, a medium long-term view introduces a positive factor: when workers are sure to be somehow compensated for the job destruction associated with technical change, the related restructuring is more easily accepted. Some European comparisons made during the early 1980s, confirm this (Boyer, 1988). Conversely, when such compensation is absent (in contemporary Russia, for instance (Touffut, 1999)), the benefits from technical change are not clearly perceived by the workers, who tend to protect the existing technologies, closely associated with the conservation of their jobs. Thus macro solidarity is better than micro egoism for the diffusion of innovations.

- Voice-representation security is present when, for instance, collective rights are granted to unions for representing workers; negotiating with firms may have the same dual impact. On one side, a form of oligopolistic power is thus introduced into the functioning of the labour market that may create a negative effect upon the level of employment in compensation for the higher wage. On the other side, the voice given to representatives of the workers may enhance commitment, and the ability to introduce new technologies or redesign the organization of the firm to the mutual benefit of the entrepreneurs and the workers (Freeman, Medoff, 1984). The German and Japanese configurations of the 1980s gave a good image of this kind of complementarity, between social rights and economic performance linked to the quality of product or the high productivity in the production of standardized goods, brought by "good” industrial relations.

- Life security is a still another component of workers' security. It can be extended from accident and illness at work to health care in general. Now, more and more, some theoreticians of economic development (Chenery and Srinivasan, 1988, Todaro and Smith, 2005) admit that the level of health is an important factor in the quality and size 
of the labour supply and, by extension, in the productivity of workers. Even for developed countries, the welfare gains associated with the extension of life expectation and the reduction of morbidity may have overtaken gains as they are measured by conventional national accounting methods (Foundation Albert and Mary Lasker, 2000). It is well known that significant externalities are operating within the health-care sector (the fight against infectious diseases, increasing returns to scale associated with vaccines, pharmaceutical research, etc.). Clearly, at the world level, the role of the welfare state in the provision of an adequate level of health care is more essential than ever (WHO, 2000).

- In the same spirit, skill security is a fourth component. Along with basic education, permanent competence building is more and more recognized as a key factor in endogenous technical change (Lucas, 1988; 1993) and in social stratification (Bénabou, 1996). The externalities are multifaceted: the educational system delivers the higher competence of workers, who develop the ability to learn along the whole spectrum of the life cycle; it also detects and trains the innovators, who are able to invent new products and processes, etc. All these gains cannot be internalized by market mechanisms, and it is why many educational systems are public or subsidized and that a minimum level of education is generally compulsory. Thus, even if education is not formally included in the strict definition of a welfare state, it is important to address this issue, and is quite relevant to the discussion of the role of public interventions in the contemporary world.

According to this framework, based on a realistic appraisal of information problems and externalities in decentralized economies, the achievement of more social justice is not always detrimental to economic efficiency. In some special cases, a synergy could emerge between a well-designed welfare state and the dynamism of innovations. A very simple model 
Figure 2 - How various securities may enhance dynamic efficiency

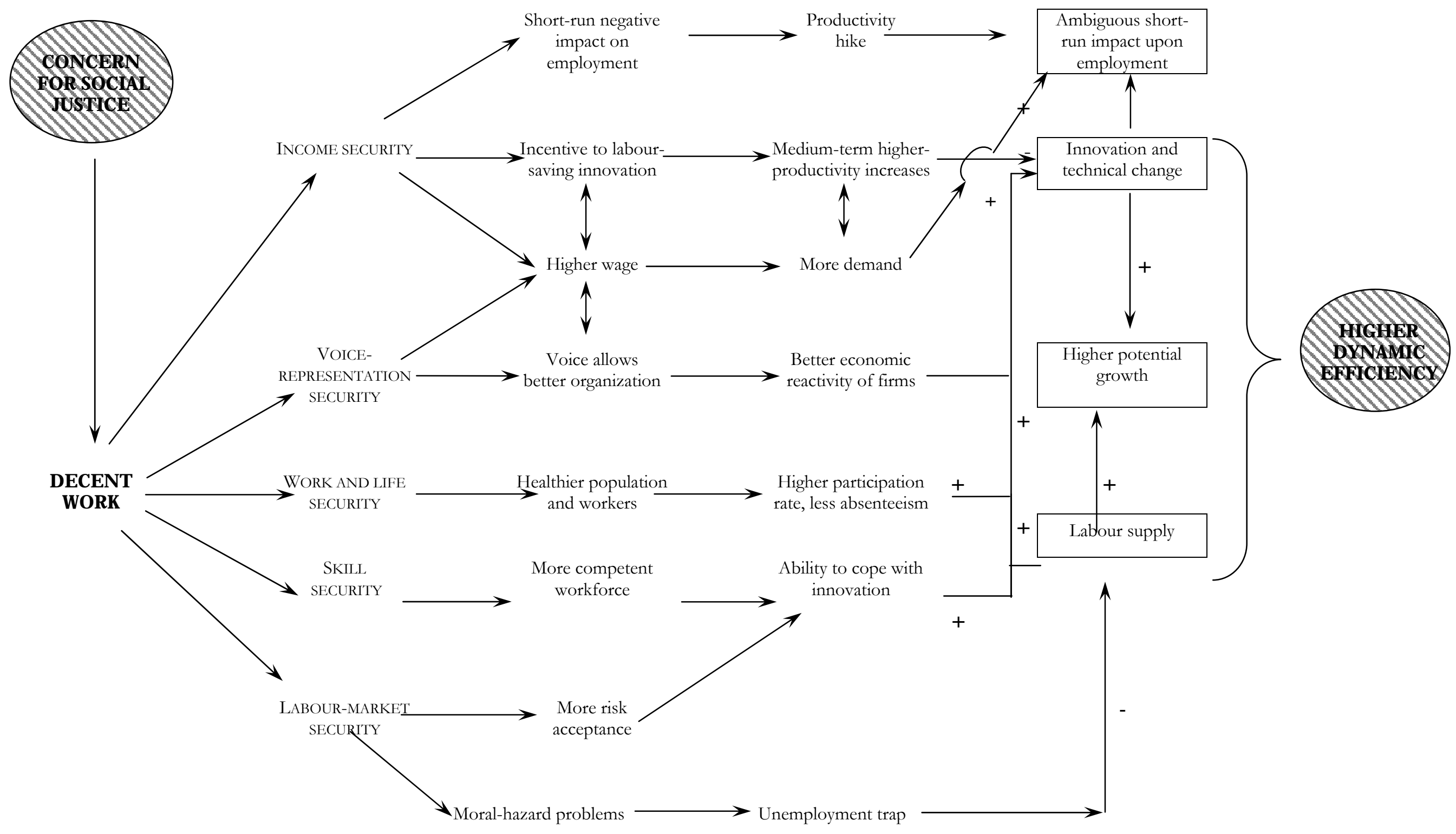


can be sketched to capture the core of the argument (figure 3). Let us imagine that a tax is levied to finance a society-wide training system: two distinct effects would then be operating and should be considered simultaneously.

- Of course, the related tax has to be paid, for instance by firms, and therefore their demand for labour would shift adversely, in such a manner that in the short term the equilibrium real wage would be lower, thereby inducing a shift from employment to leisure. Frequently, the reasoning stops here and analysts conclude that the measure is finally counterproductive: a society without a welfare state would deliver better welfare for its citizens, which is quite a paradox.

- The social tax, however, is not only a cost since it delivers a benefit and is supposed to contribute, for instance, to the financing of more education and training. Therefore, the productivity of the labour force is higher than it would be within an economy devoid of such a welfare system. Consequently, productive employment is lower but the proportion of the population that is on training increases at the long-term equilibrium. Within an endogenous technical change model, total factor productivity increases are linearly linked to the stock of human capital. If so, the steadygrowth path is higher than before and this ultimately compensates for the lost productive output during the first phase of implementation of the measure. Therefore, for a sufficiently lowactualization rate, the economy finally benefits from the collective financing of more training and education.

To sum up, the contribution to social security may affect negatively the short-run equilibrium but may induce decisions and investments that promote innovations and growth. Such a framework, even if relatively simple, allows a rigorous assessment of the pros and cons of any component of the welfare state, without concluding ex ante that it is always detrimental (this is the quasi general conclusion from typical neo-classical research) or always good (that is sometimes the propensity of the defenders of 
Figure 3 - A reconciliation of two opposed visions of the impact of welfare

A DISTURBANCE IN PERFECT COMPETITIVE EQUILIBRIUM

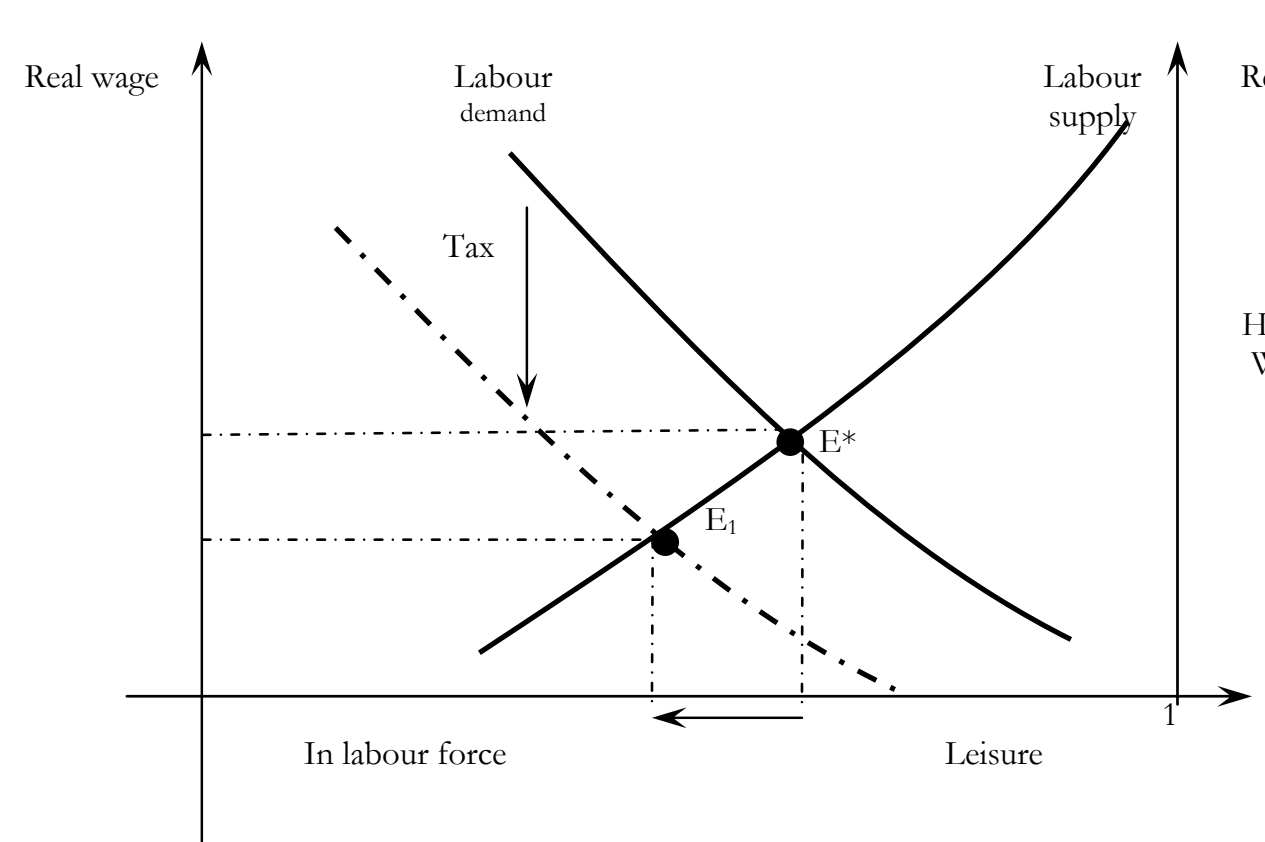

According to the first vision welfare financing by a tax on firms reduces both real wages and employment

According to the seaond vision welfare may reduce productive employment but enhance long-term productivity increases

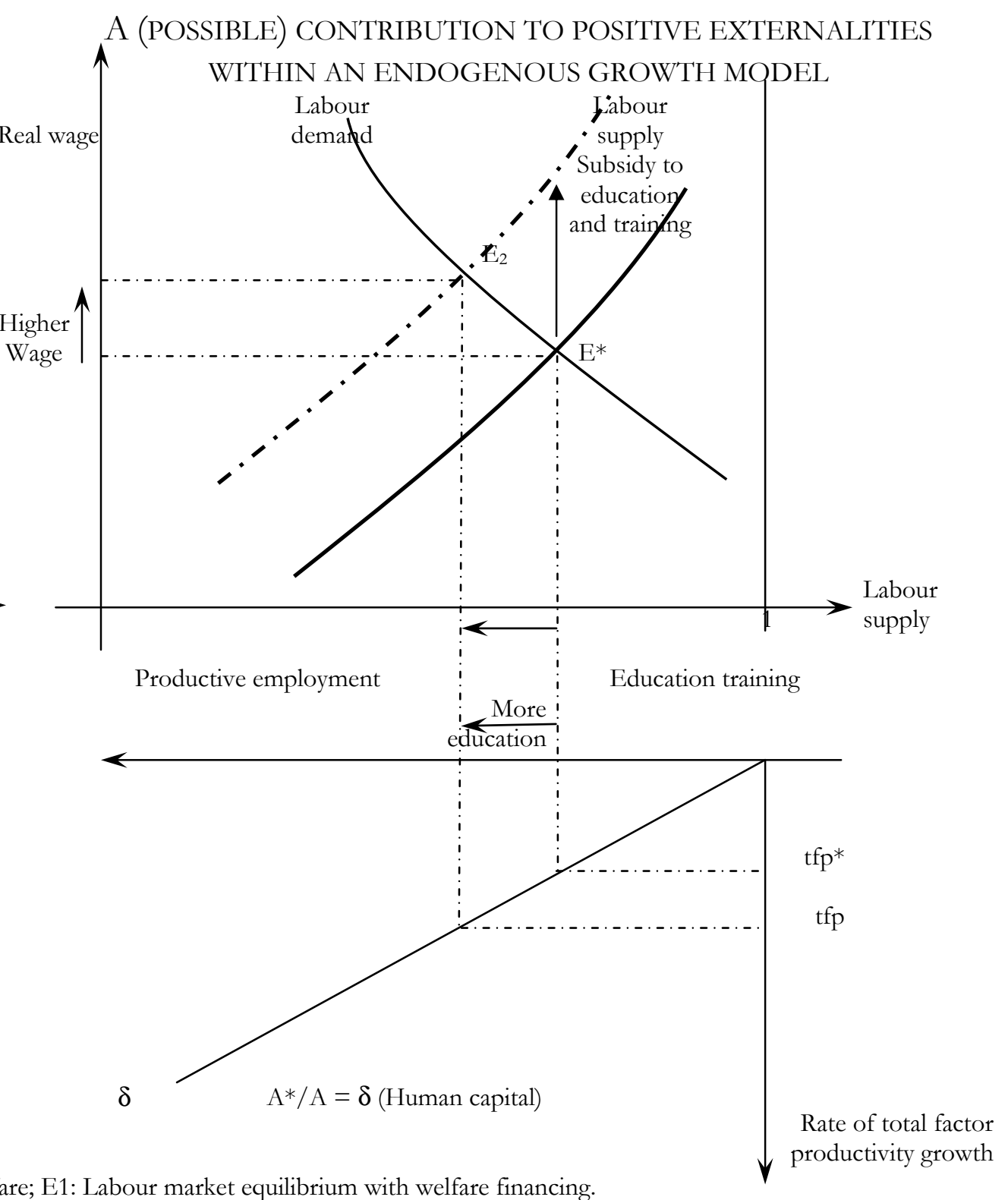

E*: Labour market equilibrium without welfare; E1: Labour market equilibrium with welfare financing. 
existing welfare states). Consequently, the assessment of contemporary welfare states is not a purely theoretical issue but, above all, a matter of careful empirical studies (Atkinson, 1999; Tachibanaki, 2000; Tachibanaki, Fujiki and Nakada, 2000). This analytical framework is relevant for developing countries as well. For instance, the Asian financial crises and the related structural reforms have made quite central the issue of the possible complementarity between the building of an inclusive welfare state and a long-term development strategy (Kwon, 2006).

\section{SOME LABOUR SECURITIES PROMOTE ECONOMIC PERFORMANCE}

It is out of the scope of the present paper to provide an assessment of some of the labour securities that promote economic performance. The paper's objective is far more modest: to deliver a brief survey of the literature according to this vision of the welfare state. Let us provide rudimentary evidence of the inadequacy of the conventional vision that puts forward only the costs and not the benefits of workers' security.

\section{Job security helps workforce redeployment}

The core argument in favour of typical labour-market flexibility is two-fold. On one side, in response to economic and technological shocks, the labour force has to be shifted from one firm to another and across sectors. Such a move warrants static efficiency that is privileged by partial or general equilibrium analyses. On the other side, when technological change is speeding up -- especially if an old, productive paradigm is decaying and a new, quite different, one is emerging -- an intensive shift of workers has to take place from the mature to the sunrise industries. The question is why workers should accept these structural changes. The reason would be only if their ex post long-term welfare could be improved, and if the transition costs were reduced by an adequate public redistribution of the benefits associated with productive increases and product differentiation. 
An international comparison suggests that job security is quite beneficial to the acceptance of change and the move from bad to good jobs (figure 4). Of course, the relationship is not that simple. On the one hand, Ireland, Netherlands and Denmark do combine job security and very high transition rates from obsolete to emerging jobs. On the other hand, the United Kingdom of Great Britain and Northern Ireland defines a second configuration whereby a high level of insecurity induces significant mobility. This is an important caveat for any temptation to single out one particular best-way model. Institutional economics explain why: there exist different complementarities between the nature of competition, the organization of the labour market, the generosity of the welfare, and the direction and intensity of innovation (Aoki, 2001; Amable, 2003).

Figure 4 - Quality of job prospects and insecurity, selected European countries, 1995-2000 (percentage)

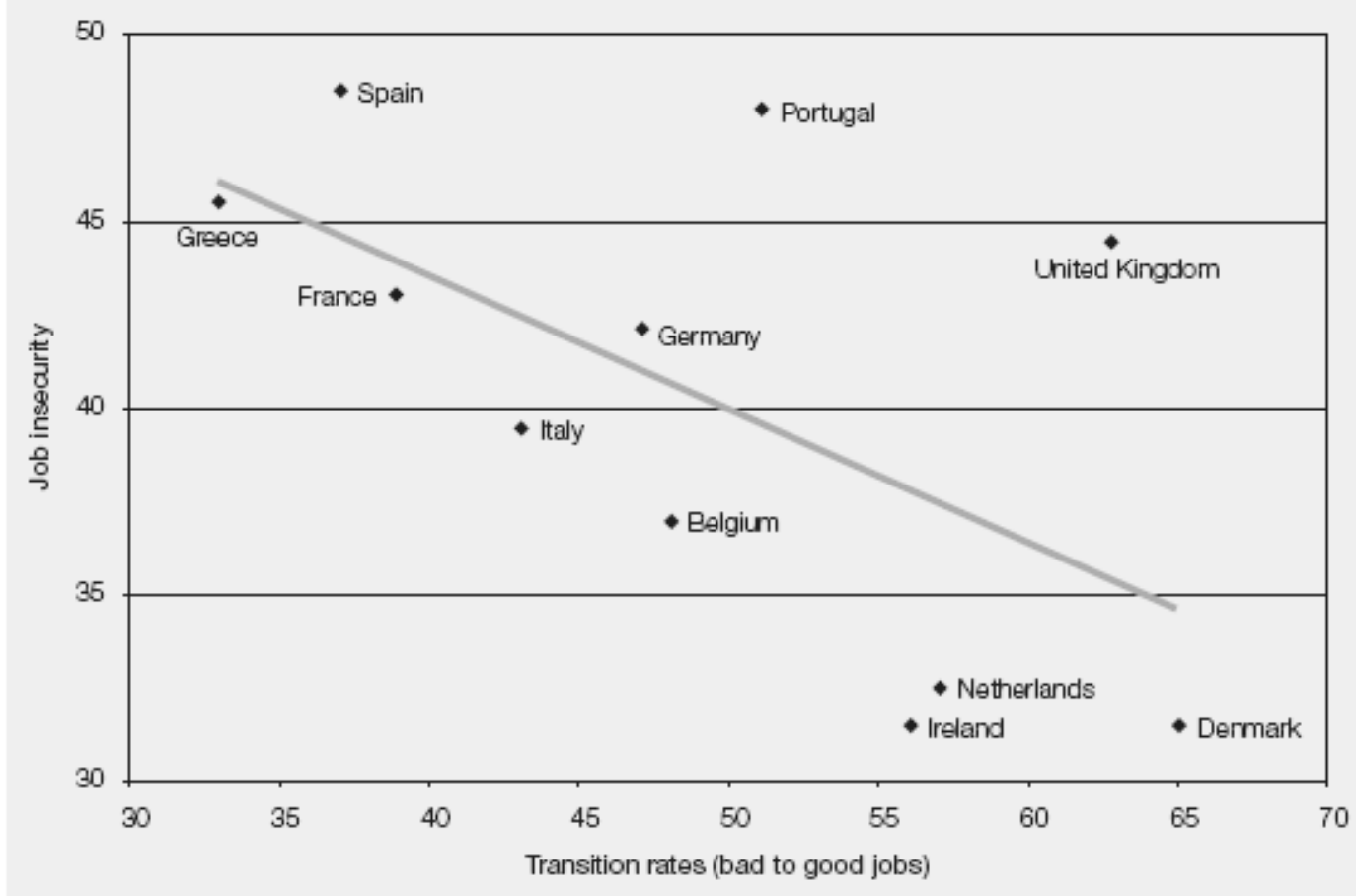

Note: Transition rates from low-quelity to gocd-quality jobs are maesured in percentegas and are based on a Eurcpean Commission survey conducted during 1995-1998. Jobe are categorized depending on pey, productivity, job securty, treining copportunities and career prospects. Job insecurity data measures the percentage of workers who are unsure of a future with their employer even if they perform their job well.

Sources: Eurcpean Commission, 2002. Data for 2000 besed on the Intemational Survey Reeearch databese, various years.

Sourœ: ILO (2004a), p. 206. 


\section{Labour-market policies can reduce job insecurity}

Left alone, the functioning of highly competitive labour markets does not provide the job security that workers expect, for various reasons. First, modern labour-market theory suggests that full employment is the exception and the equilibrium with unemployment or scarcity of workers is the rule. One of the objectives of macroeconomic policy is precisely to maintain the economy close to quasi full employment, but the task has become more and more difficult, especially in Europe. Second, in case of unemployment, the access to employment can be restricted to the most skilled and productive workers, leaving the less privileged in long-term unemployment. It is why active labour-market policies have to be designed and implemented.

Precise, empirical analyses among OECD countries confirm the existence of a significant correlation between job insecurity and the poor spending on employment policies (figure 5). Again, among the star performers in terms of security, one finds the same countries as for figure 4: Netherlands, Ireland and Denmark. At the opposite end, the United Kingdom and the United States of America, as well as the Republic of Korea (South Korea) and Japan, are characterized by a low degree of intervention in the functioning of the labour markets and quite high job insecurity. 
Figure 5 - Job insecurity and spending on labour market policies, selected OECD countries, 2000

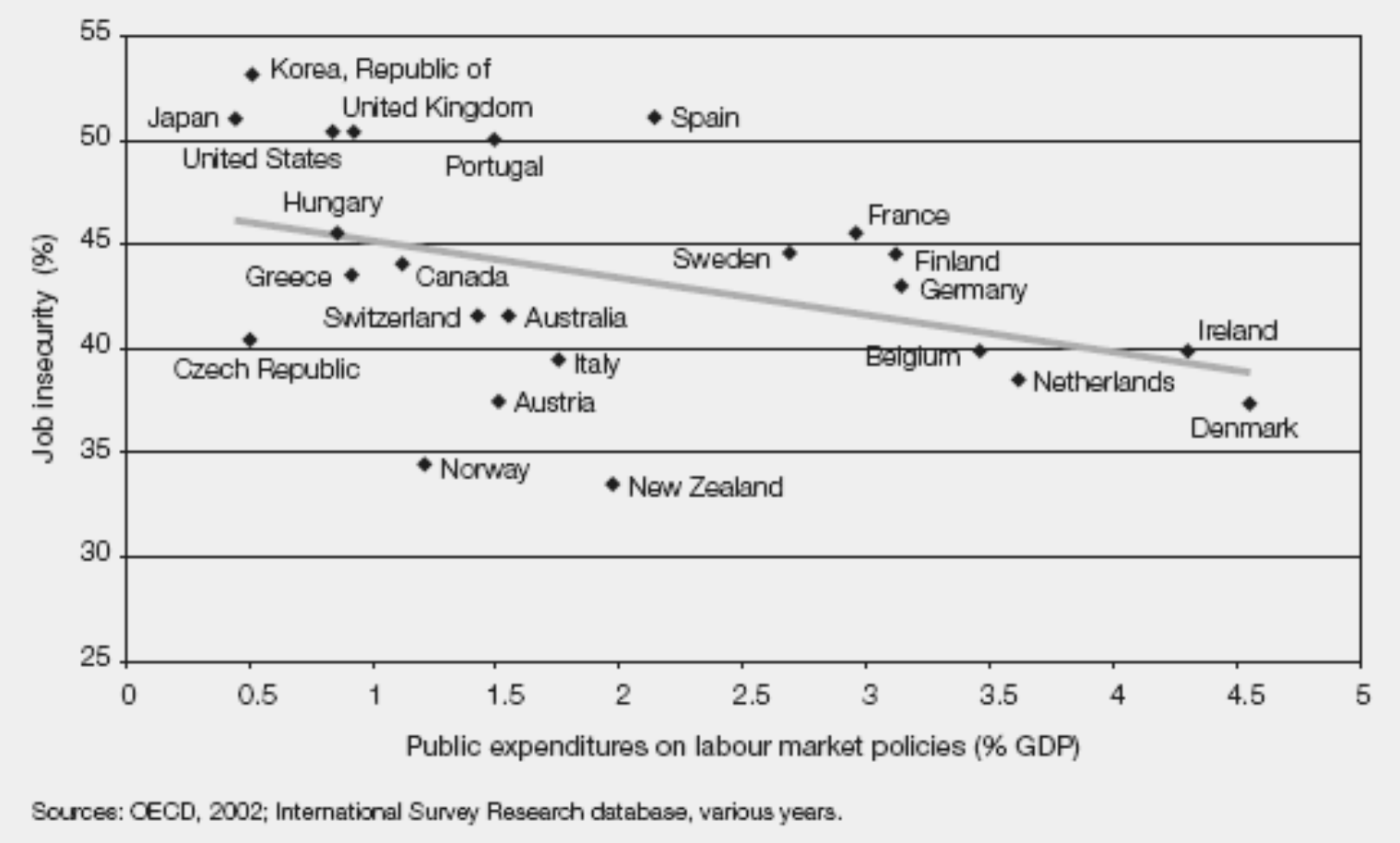

Sourœ: ILO (2004a), p. 207.

\section{Small, open economies have more active employment policies}

Conventional economic theories generally suggest that small and very open economies need greater flexibility than medium-sized or large countries. Basically, they should be price takers, and thus unable to finance the extra costs associated with a generous welfare state promoting workers' security. This stylized fact is not at all confirmed by international comparisons among OECD countries. At one extreme, large and not so open economies, such as the US and Japan, do not spend large amounts for employment policies. At the other extreme, Finland, Sweden, Netherlands and Belgium combine a large openness to world trade with a major influence on labour-market policies (figure 6).

Political economists provide a quite appealing interpretation of this situation. When the welfare of citizens is highly dependent on successful integration in the international division of 
labour, simultaneously some major risks do occur due to the fast and frequently unexpected variations in the demand, exchange rate and price in the international economy. Therefore, according to a long historical process, these small, open economies have found that extensive welfare and redistributive tax systems are the permissive conditions for the acceptance by workers of international competition and the related uncertainty. Of course, this is not at all a functionalist or mechanical process, since social movements and politicians have to convert these pressures into acceptable compromises between labour and capital (Katzenstein, 1985). These findings are both a hope and a challenge for developing countries: on the one hand, their opening to the world economy might be associated with new risks that call for the design of solidarity procedures to share the benefits of the winners with the losers; on the other hand, the design and implementation of adequate labour laws and welfare benefits are quite difficult tasks, especially for politically unstable countries that have poor institutional capacity.

Figure 6 - Spending on labour-market policies (LMP) increases with openness: selected industrialized countries, 1970-2000

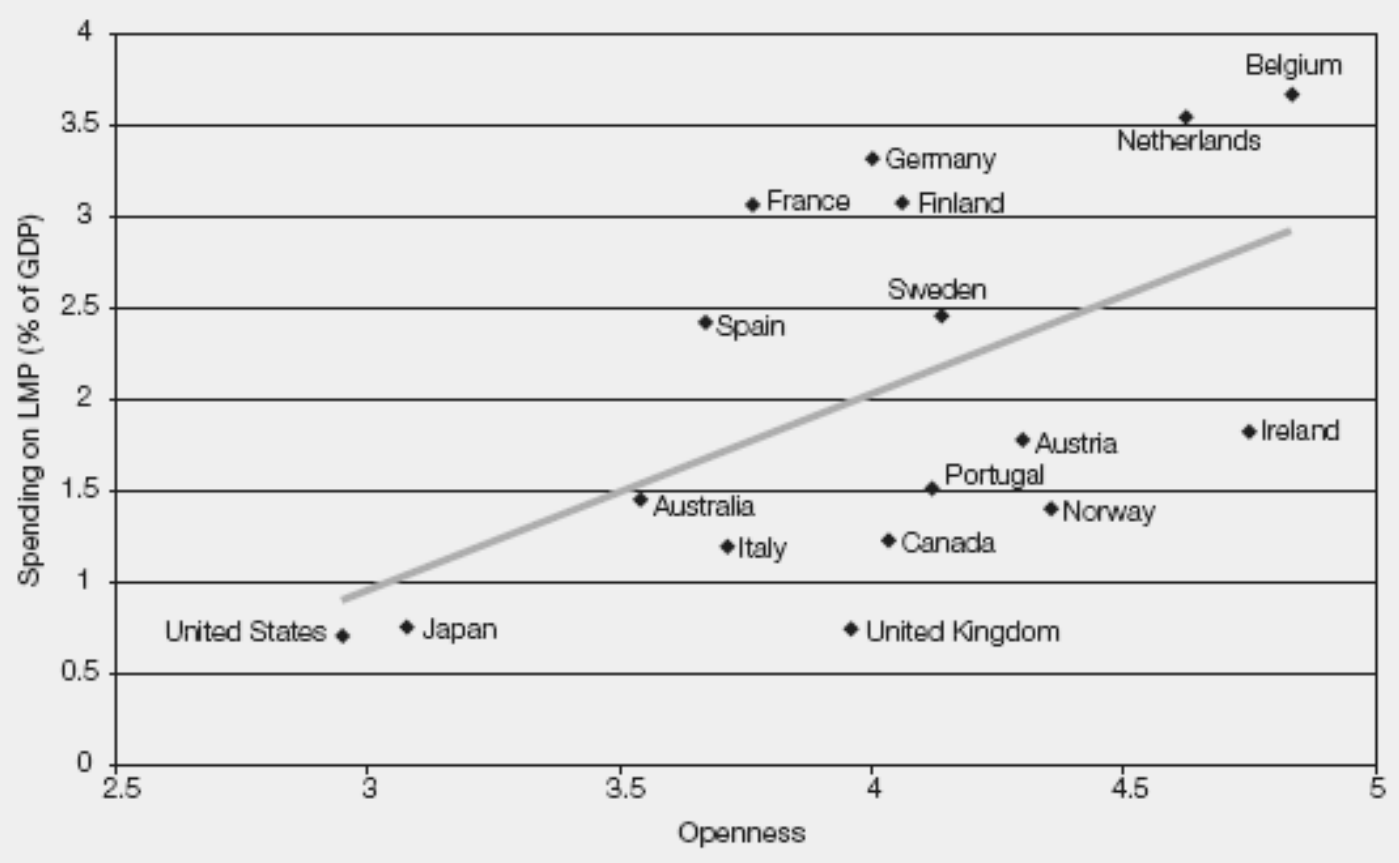

Note: Openness index is caloulated as the natural log of the averege ratio of exports plus impcrts to GDP during 1971-1929. Sources: OECD, 2004; Dar and Amirkhelkhal, 2003.

Source: ILO (2004a), p. 190. 


\section{Active welfare may be complementary to innovation policy}

One could expect that the economies with the most intensive redistribution via welfare should be lagging in terms of macroeconomic performance. On the contrary, it is surprising to find out that the countries with the leaner welfare benefits are not necessarily at the forefront of technological innovation and that most of the small, open economies with extensive welfare have been faring quite well during the last decade (Denmark, Finland, Sweden, etc.), with total factor productivity increases rivaling the so-admired American "New Economy" (figure 7). The recent research, carried out under the aegis of OECD to explain why growth rates differed so much during the 1990s, has shown that these European economies are already operating under the virtuous circle that is assumed to be typical of a Knowledge-Based Economy (KBE) (Bassanini, Scarpetta and Visco, 2000; OECD, 1999; Guellec, 2000).

Figure 7 - Change in multi-factor productivity (MFP) growth and change in business research

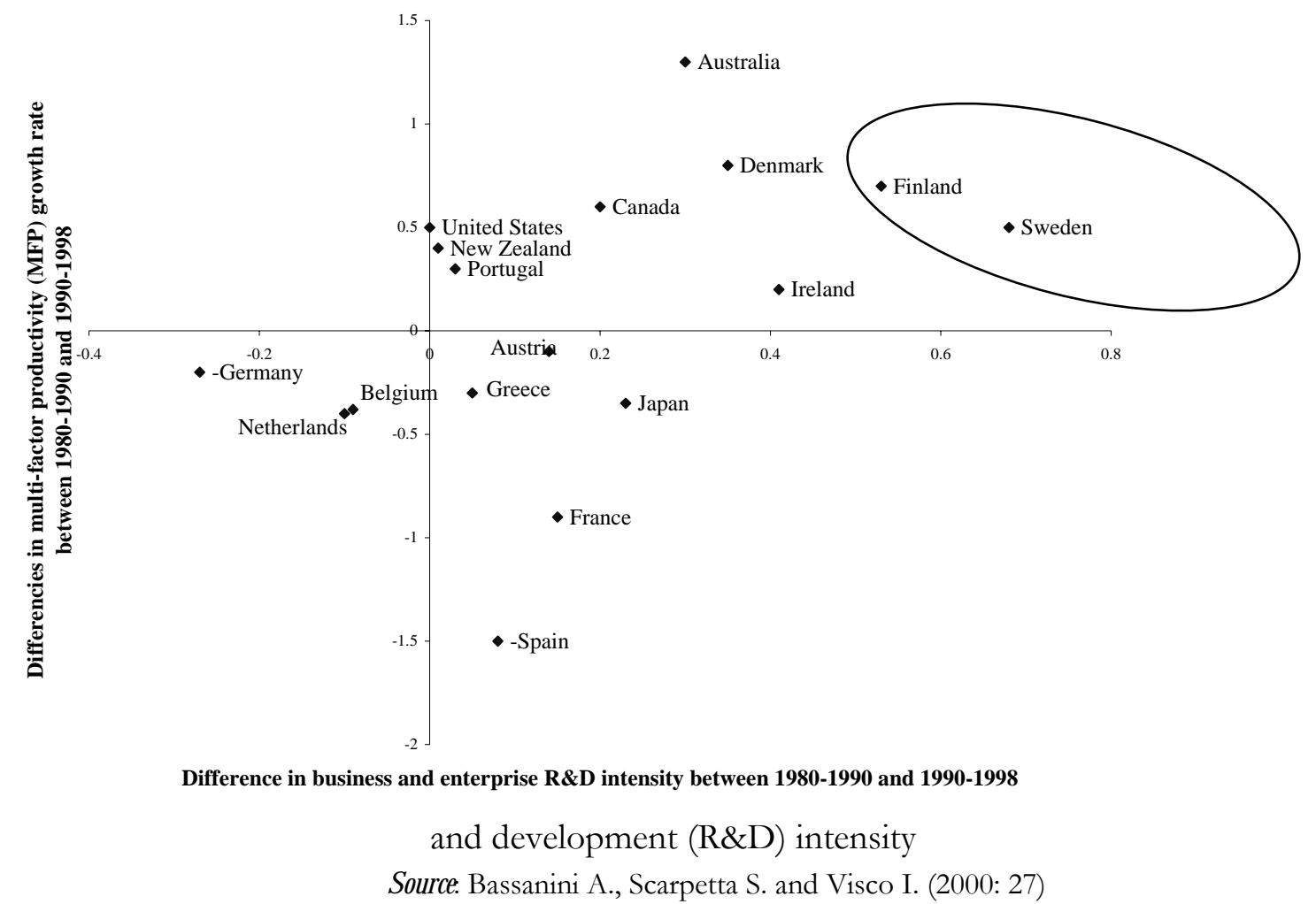




\section{A whole spectrum of configuration for workers' security}

Thus, international comparisons falsify the conventional hypothesis of a single best way for the organization of welfare. A priori, one should observe a very large variety of ways, combining income security, voice-representation security, life security and skill security. Actually, the existing configurations are less diverse, probably due to the existence of complementarity as well as some major incompatibilities between these various forms (table 1).

Table 1 - Employment or employability protection? A typology of OECD countries during the late 1990s and early 2000s

\begin{tabular}{lll}
\hline & High social protection & Low social protection \\
\hline High & Tenure: $2^{\text {nd }}$ longest & Tenure: longest \\
employment & LMP spending: $2^{\text {nd }}$ greatest & LMP spending: $2^{\text {nd }}$ least \\
protection & Job security laws: $2^{\text {nd }}$ strictest & Job security laws: strictest \\
& Job security perception: $2^{\text {nd }}$ highest & Job security perception: lowest \\
Countries & France, Germany, Sweden & Japan, Portugal, Greece, Italy, Spain \\
Low & Tenure: $2^{\text {nd }}$ shortest & Tenure: shortest \\
employment & LMP spending: greatest & LMP spending: least \\
protection & Job security laws: $2^{\text {nd }}$ most lenient & Job security laws: most lenient \\
& Job security perception: highest & Job security perception: $2^{\text {nd }}$ lowest \\
Countries & Denmark, Belgium, Netherlands, & United States, United Kingdom \\
& Finland, Ireland &
\end{tabular}

Sourœ: ILO (2004a), p. 209.

Basically, for developed countries, two major tools have been used in reaction to workers' demands and the nature of insecurity. On the one hand, some Governments might be tempted to protect existing jobs, and this is employment security stricto sensu. Typically, Mediterranean European countries belong to this model. On the other hand, social partners might prefer to accept intensive job destruction and creation in return for a safety net that provides high income security for the displaced workers in response to competition, technical change or crisis. Again, the small, open economies previously mentioned, Denmark, Belgium, Netherlands, Finland and Ireland, belong to this configuration. Two composite cases exist. A third group, composed of the US and the United Kingdom, simultaneously exhibits low social protection and very weak employment protection. A hybrid configuration combines both high social coverage and employment protection: France, Germany and Sweden. 
Thus, this brief survey of the links between labour-market flexibility and workers' security in OECD countries delivers an important message: according to economic specialization, degree of opening and the nature and history of social political demands, various mixes of flexicurity can be observed. Therefore, flex-flexicurity is almost an exception and hardly the rule. For many dimensions of labour, the maximum flexibility is not an optimum and, thus, a convenient degree of security is not detrimental to dynamic as well as static economic efficiency.

\section{DEVELOPING COUNTRIES: QUITE SPECIFIC CONDITIONS}

A priori, many structural conditions differ between developed and developing countries. Therefore, it is not a surprise if the configuration of flexicurity cannot be copied easily, even among closely linked European countries (Boyer, 2006). The major transformations of the world economy, however, as well as the paradigm shift of productive models associated with Information and Communication Technologies (ICT) and, of course, domestic social demands, open up the possibility of some improvements which would reconcile employment creation and decent work. Some recent advances in development theories propose an interesting tool to assess what are the key factors that limit growth and employment: in some instances, the promotion of worker securities may simultaneously improve the welfare of the society and macroeconomic performance (Hausmann, Rodrik and Velasco, 2005). Another crucial issue relates to the tools available to create, implement and monitor worker securities. The challenge might seem quite severe, but the good news is that some developing countries have been rather, or at least quite, successful in promoting elements of a decent work policy.

\section{Constraints and opportunities regarding productive employment and decent work}

The objectives of productive employment and decent work should be universally valid, but bearing in mind the specific features of different groups of countries their achievement calls for quite contrasted institutions, mechanisms and ways of achieving them (Ghai, 2002). Basically, if 
the need to compete via product differentiation and innovation is an incentive to flexicurity in the context of high-employment rates in the formal sector, by contrast, most developing countries suffer from two structural obstacles to the diffusion of decent work and security. First, an impressive labour surplus leads to the domination of informality regarding, for example, the absence of labour contracts and the legal status of an activity, as well as the avoidance of taxes. It is especially so for the rural sector, which is largely associated with the domination of agriculture. Consequently, the implementation of ILO standards is highly problematic for developing countries which specialize in the production and export of primary commodities.

Second, collective action in favour of workers' security is made difficult because Governments and public administrations have neither the resources nor the ability or legitimacy to implement economy-wide labour standards. Similarly, workers' unions are difficult to organize, or even do not exist in the informal sector.

Furthermore, developing countries experience a larger macroeconomic volatility than industrialized economies, in the context of low-income levels that make insurance for workers difficult to finance. The pro-cyclicity of public budgets is another hindering factor. Paradoxically, financial globalization, which was supposed to help poor countries to alleviate economic downturns, seems, until now, to have had the opposite impact, i.e., it has created new sources of crises, especially for Asian countries. This has been quite detrimental because these crises have reduced long-term growth of poor countries (Cerra and Saxena, 2005). The number and severity of these constraints may suggest that the strategy proposed by ILO is hopeless for developing countries (table 2). Some (modest) countervailing forces are, however, pointed to in the literature. 
Table 2 - Obstacles and opportunities for decent work in developing countries

\begin{tabular}{|c|c|}
\hline $\begin{array}{l}\text { 1. Large, hidden obstacles to open } \\
\text { employment; large informal sector }\end{array}$ & $\begin{array}{l}\text { - Frequently attributed to the excessive } \\
\text { security granted to the formal sector }\end{array}$ \\
\hline 2. Weak States & $\begin{array}{l}\text { - Social compact } \\
\text { - Role of consumers of third- world } \\
\text { products }\end{array}$ \\
\hline 3. Weak/non-existing unions & $\begin{array}{l}\text { - Institution of representative unions by } \\
\text { State regulation }\end{array}$ \\
\hline $\begin{array}{l}\text { 4. Low-income levels and resources for } \\
\text { insurance }\end{array}$ & $\begin{array}{l}\text { - Human development: a condition as well } \\
\text { as an outcome of economic development }\end{array}$ \\
\hline 5. Rural activity as structurally uncertain & - Move from agriculture to services \\
\hline 6. Large macroeconomic instability & $\begin{array}{l}\text { - The smaller the economy, the likelier more } \\
\text { flexibility, and significant welfare }\end{array}$ \\
\hline $\begin{array}{l}\text { 7. More uncertainty with the opening to the } \\
\text { world economy }\end{array}$ & $\begin{array}{l}\text { - Globalization may be a trump: } \\
\text { - Higher wages for multinationals } \\
\text { - } \text { Higher wages in the export sector } \\
\text { - Codes of conduct }\end{array}$ \\
\hline 8. Rare public training & $\begin{array}{l}\text { - Shortage of skilled labour as an incentive } \\
\text { for upgrading competences }\end{array}$ \\
\hline
\end{tabular}

- It is at first difficult to consider that the relative security granted to the small number of workers employed in the formal sector is the reason for the lack of protection of informal workers. The argument may apply to OECD countries, where a large sector protected by labour laws is complemented by atypical labour contracts that bear most of the required flexibility in reaction to uncertainty. In developing countries, however, the ocean of flexibility of informal work is not the necessary complement of the rare islands of relative security: the high flexibility is the direct consequence of the productive structures, the nature of demand, and, eventually, the style for macroeconomic policy. The diversity of informal work has be recognized and carefully analysed (Chen, 2006), and the complex relations between the formal and informal sectors should be understood before addressing the issue with a strategy of progressive formalization of informal work. 
- Given the pressures towards more flexibility even for previously protected workers, the distance between formal and informal employment could be reduced by progressive steps in granting some rights to informal workers, compatible with the employment decisions of entrepreneurs. The long-term goal could thus be to open a path in the direction of "a single regime with qualified tolerance and minimum floors" (Tokman, 2006). Symmetrically, a simplification of property titles and a form of de jure recognition of de facto property could help in fostering entrepreneurship, thus creating more wealth and alleviating poverty and insecurity (De Soto, 1986). In both cases, the recognition of rights may foster production and employment.

- The low level of surplus available for accumulation is a strong incentive to allocate scarce resources to the more productive investments. The formation of human capital, in education and health, appears as a powerful lever in the promotion of development since it delivers more competences and life security (Todaro and Smith, 2005). This is, simultaneously, the input and the output of the process of development: quality of life and work security do evolve along with growth.

- Per se, macroeconomic instability - either typically domestic or implied by the vagaries of the world economy - should be an incentive to search for mechanisms providing one form of security or another to people, and especially workers. This need is fulfilled, however, only if collective action allows for the design of the equivalent of insurance mechanisms: business associations, workers' unions, non-governmental organizations (NGOs) and civil servants are required to discuss, negotiate and agree to build the various components of a welfare state. Actually, the more open the developed economies, the larger the spending on welfare, including active labour-market policies (see figure 6). This process took nearly a century, and is continuing in response to the structural changes of the last decades. It should not be a 
surprise, therefore, if poor countries experience similar difficulties in building their welfare states in the epoch of trade liberalization, financial globalization and productive paradigm shifts. The organization of collective actors as well as the effectiveness and legitimacy of the State are among the discriminating variables. This might well be a convincing explanation why national trajectories differ so much between Africa (Nkurunziza, 2006) and Latin America (Pagès, 2003), or even within East Asia (Kwon, 2006).

\section{The ambiguous impact of globalization on labour standards}

The impact of the world economy on the perceived trade-off between employment and decent work is far more complex than the pro- and anti-globalization forces generally assess. It is simply because internationalization has many distinctive components, with contrasted impacts, and because national economies differ drastically in this respect (figure 8).

- When trade opening contributes to the dynamism of a manufacturing export sector using modern technology, generally the welfare of the related workers is improved, South Korea being a good example (Kwon, 2006). When a rapid and general decrease in tariffs takes place, however, the destruction of manufacturing competences and high-wage jobs may correlate with a return to a quite regressive specialization in natural resources (Boyer and Neffa, 2004), with little job creation. This results in a large widening of inequalities (Waisgrais, 2002) and the diffusion of work insecurity across a large section of the population, as was the case in Argentina.

- It is now widely recognized that trade and financial openings are not equivalent (Prasad and others, 2004): on average, trade enhances welfare, whereas opening to finance has not such a positive effect, and provokes an increase in the probability of financial crises. Since growth 
rate is reduced after such episodes, the global impact, until now at least, has frequently been detrimental to work security.

Figure 8 - Chances and constraints on productive employment and decent work

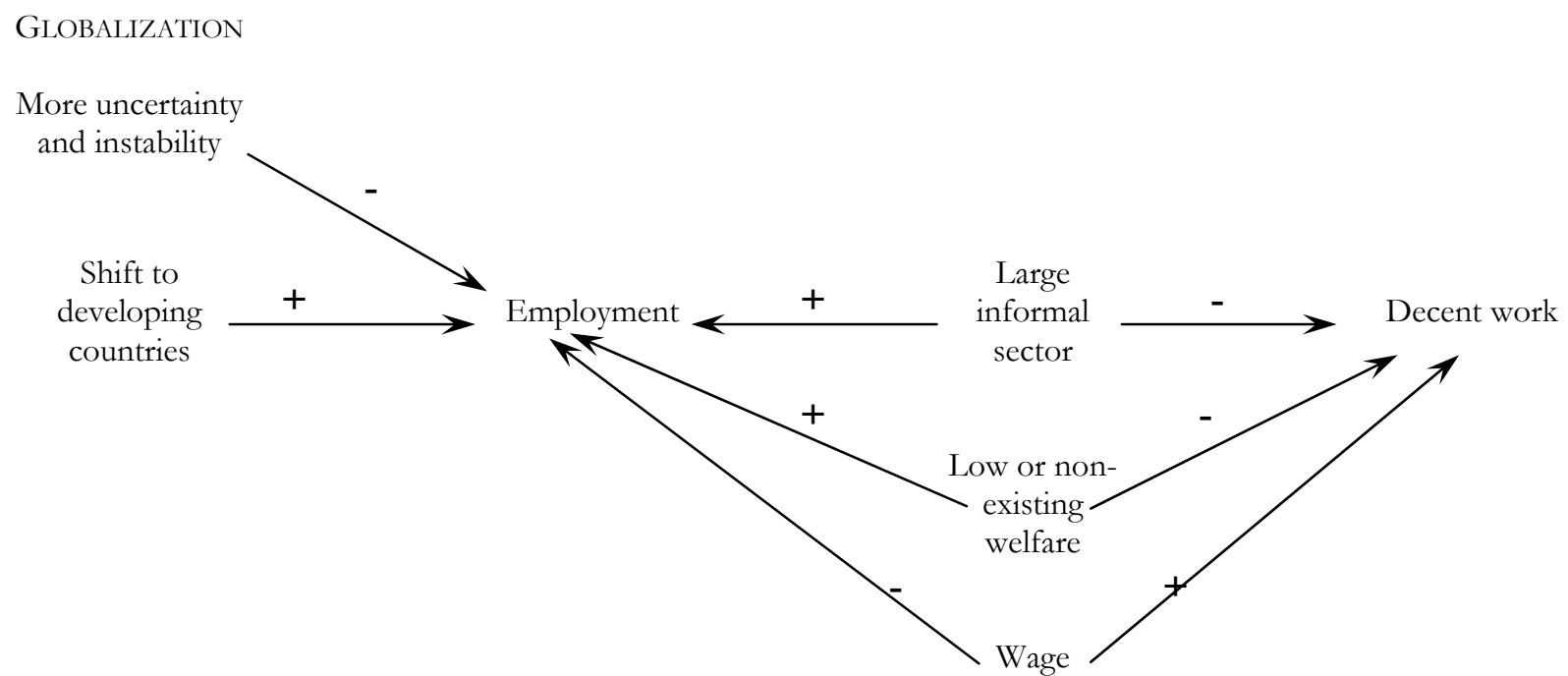

- The opening of capital accounts may have quite contrasted outcomes. In theory, Foreign Direct Investments (FDI) develop domestic productive capacities, and frequently contribute to export. Some empirical studies suggest that the "conventional wisdom" that foreign investors favour countries with low labour standards is not confirmed (Kucera, 2001). Actually the degree of workers' rights may go along with political and social stability and human capital development. By contrast, portfolio investment brings frequently brusque and unwarranted inflows that distort the terms of trade and the productive structures in favour of the sector producing non-tradable goods. The related boom ultimately ends by a sudden stop of capital inflow (Kalantzis, 2006). In developing countries, this means a severe recession and, frequently, political programmes that promote "labour flexibility". The final outcome is a growth slowdown, and more insecurity in labour contracts for a large part of the population. 
An optimistic view could consider that if the sequencing of the opening were correct trade, foreign investment, portfolio investment - globalization could help promote some labour standards (Ghose, 2003: 95-109), while contributing to productive employment.

\section{Employment diagnosis: A method for drawing a dividing line between flexibility and security}

Quite rightly, the UN/DESA Development Forum on Productive Employment and Decent Work stressed that productive employment was the primary component of any prolabour policy. This paper has tried to show that the maximum flexibility is generally far from the optimum in terms of economic efficiency. The issue is then to determine what should be the most convenient flexibility/security mix compatible with the objective of job creation. The answer cannot be derived from pure theory, since the precise structural conditions have to be analysed in each national, regional or local context. In a sense, this is a drastic reversal with respect to the legacy of the so-called Washington Consensus, according to which the same general menu was supposed to fit all domestic contexts.

The question is whether the relevant tools are available to make such an analysis. The long experience of development economics has recently provided quite an interesting and stimulating method to cope with the diversity of developing as well as developed countries. The growth diagnostics approach (Hausmann, Rodrik and Velasco, 2005) proposes systematic review of the multipliers associated with the relaxation of the various constraints inhibiting economic activity and the design of economic policy and reform of economic institutions, accordingly. In some instances, a policy that delivers quite impressive results in one country may be inefficient or, worse, detrimental to growth in another. For instance, the authors find that a sound macroeconomic policy is far from being a sufficient condition for growth since the long-term trajectory is shaped by factors quite different from those that would shape the short-term equilibrium. In other words, static efficiency - frequently associated with price flexibility - has to 
be distinguished from dynamic efficiency, i.e., the ability to improve, cumulatively, productivity and the standards of living of an entire population.

It might be useful to rejuvenate a macroeconomic theory that was quite enlightening in the 1980s in order to propose an analytical framework that would transcend the opposition between Keynesian and neoclassical conceptions of the determinants of employment (Benassy, 1982). Actually the so-called disequilibrium theory exhibits a series of determinants of employment. Unemployment is Keynesian if the limiting factor is effective demand; classical if low profitability limits hiring; and Marxist if the scarcity of productive capacity is the origin of low employment. When applied to developing countries and to the analysis of the links between employment and various forms of workers' security, this framework delivers three major lessons (figure 9).

- In many cases, the issue of labour-market institutional reform might be irrelevant, since the disequilibrium originates from totally different factors: an overvaluation of the domestic currency, an excessively high interest rate due to the lack of credibility of economic policy or bad management of firms, etc. In such a context, the search for wage flexibility, for example, may deliver second-order results, since this is not the relevant constraint on growth. Too often, in the 1990s, financial disequilibria have triggered excessive downgrading of workers' security in terms of wages, work intensity, welfare, etc.

- In some instances, employment levels can increase by strengthening precise forms of workers' security. For instance, if unemployment is Keynesian, more income security for workers has a positive impact both on employment and profit rate. Similarly, when firms are limited by a scarcity of skills, a policy developing workers' competences simultaneously 
Figure 9 - A growth diagnostics approach to employment creation

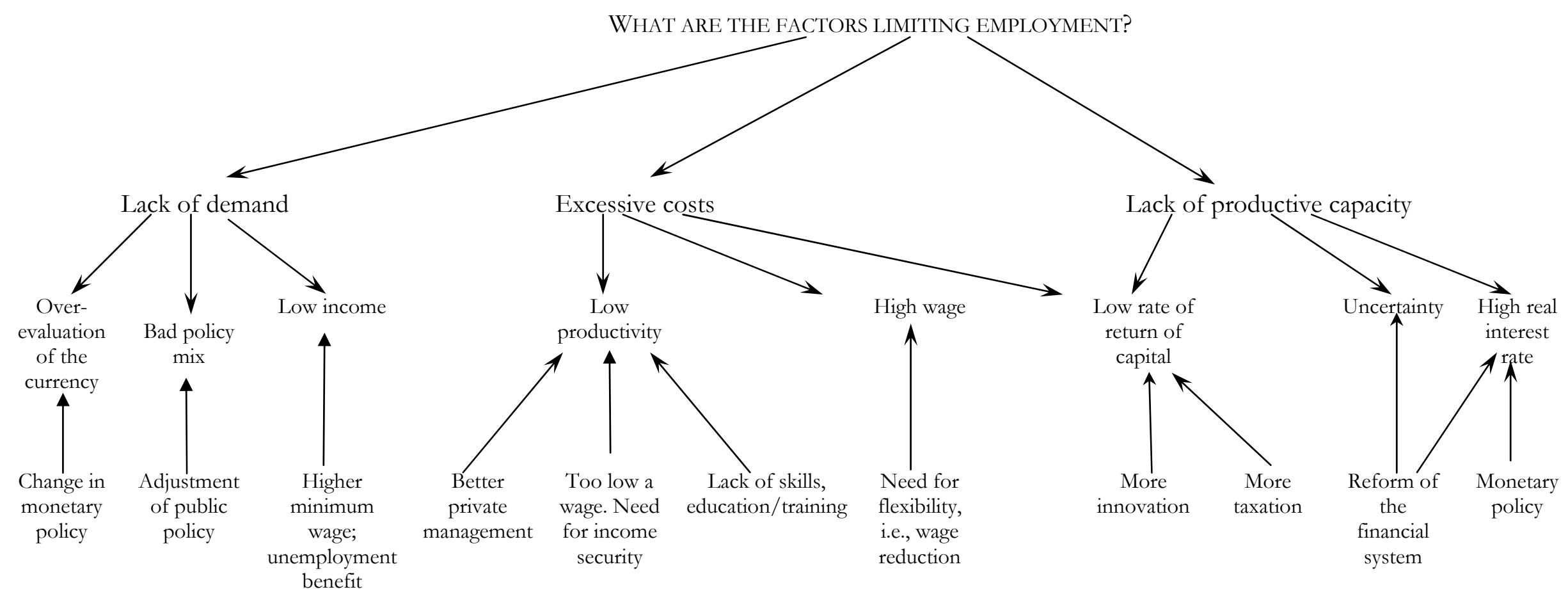


- improves macroeconomic performance and promotes welfare, and possibly reduces income inequality. In this case, there is a complementarity between employment levels and the form of worker security. Nevertheless, this is not necessarily the case, and the mix between flexibility and security has to be tuned to the precise local situation at a given historical period.

Within a third configuration, labour flexibility might be required to increase productive employment if, for instance, classical unemployment is the main source of macroeconomic disequilibria. Alternatively, some collective agreements can codify automatic indexation to inflation and productivity, and this configuration might appear unable to react effectively to new macroeconomic shocks. This case was quite frequent in the 1970s and 1980s, but nowadays the majority of developing countries are suffering from the opposite disequilibrium: productivity increases mainly feed profit increases and relative prices decline, but wages increase only marginally. The likelihood of this third configuration is now quite small in most developing countries.

Consequently, each country has to find is own mix between security and flexibility. At this level of generality, there are configurations that fulfill the same objective as the flexicurity model, but with totally different institutional settings, since productive structures, social values and political choices differ significantly from one country to another. Even within the same national economy, the coexistence of defensive flexibility can be observed in some clusters -- i.e., via wage reduction and work-intensity increase -- along with offensive flexibility in others, where the building of individual and collective competence is the main answer to technical change and the evolution of world competition (Vijayabaskar, 2005). 


\section{What are the best methods for promoting decent work?}

A brief retrospective analysis of contemporary developed countries suggests that the high security levels have been reached by a long-term historical process. The very unfolding of industrialization, sometimes called modernization, triggered large social transformations that generated new forms of insecurity (industrial injuries, unstable employment, obsolescence of traditional skills, and volatility of income). Workers were hurt by these structural changes and have thus voiced social demands in favour of mechanisms restoring a form of security. Similarly, major economic and financial crises, as well as world wars, have strengthened the bargaining power of workers and in a position to express strong demands for protection from States and Governments. As a consequence, rights to security have been embedded simultaneously into labour laws passed by Governments and into collective agreements negotiated between business associations and workers' unions. In spite of some social deregulation, developed countries continue to exhibit high levels of workers' security (table 4).

As previously mentioned, few developing countries actually experience such a process of industrialization, with the noticeable exceptions of China and India. Therefore, most developing countries have to follow other paths in the direction of better worker security (table 3).

- International organizations, especially ILO, are in charge of designing and diffusing some basic labour standards via the use of international conventions. This process is quite useful in analyzing the diversity of national experiences and creating a community in charge of diffusing these international norms. Nevertheless, national Governments may or may not sign these conventions. Even when these conventions exist, their implementation is entirely left to the initiative and interest of national Governments. These international pressures 
become more effective when they are taken up by groups of domestic actors who ask for the explicit recognition of these international labour norms.

- Given the key role of transnational corporations, it would seem that it would be in their long-term interests to cope with a decent approach to labour management all over the world. If their consumers are ready to pay a premium in order to be sure that ethical norms are respected when production is delocalized all over the world, such an equilibrium may be self-fulfilling. Nevertheless, it is not sure that such a virtuous circle - the consumers of the developed world disciplining the multinationals - can be generalized and that it is strong enough to replace the role of hard law in Western countries (Levis, 2006; Lobel, 2006).

- Non-governmental organizations could complement the two previous mechanisms. First, they can report to the international organizations the degree of fulfillment of international labour norms and thus help to enforce them by "blaming and shaming". Second, they can organize discussions and bargain with transnational corporations, and they are well equipped to do so since most NGOs are transnational too. The difficulty is that a plurality of NGOs, with different and sometimes contradictory objectives, cannot replace the centrality of national governance and cannot be a substitute for a true power of coercion, the power of a unified, but non-existing, world government.

Table 3 - The paths to workers' security

\begin{tabular}{|c|c|}
\hline \multicolumn{2}{|c|}{ WHAT CONDITIONS WOULD FAVOUR DECENT WORK? } \\
\hline - Business codes & - Corporate Social Responsibility (CSR) \\
\hline - National labour law & - Scarcity of workers \\
\hline - Collective voice of workers & - Full employment \\
\hline - Social conflicts & \\
\hline - Social compacts & \\
\hline
\end{tabular}


The mobilization of domestic actors is therefore crucial, since business codes, corporate social accountability, social compacts are only partial substitutes for the process generated by hard law, as observed in old, industrialized countries.

\section{Some developing countries do succeed}

In the light of the previous arguments, it will come as no surprise that the global index of economic security, elaborated by the ILO Socio-economic Security Programme, shows that the majority of best performers do belong to OECD (table 4). The only exceptions are four Eastern and Central European countries; this can be interpreted as a legacy of the order, inherited from the Soviet-type regime, where the State was warranting strong security to workers in exchange for compliance with political authorities.

No developing countries are part of the group of pacesetters, but Mauritius, South Africa, Costa Rica and Chile, as well as Estonia, Lithuania and Slovakia, belong to this group: in terms of outcomes these countries are quite successful in spite of a poor score on inputs and processes governing worker security.

The majority of other countries belong to a fourth group, characterized by less effective security and low institutional mechanisms to obtain it. Most African countries are part of this group, as well as some Latin American countries. China and India are present in this group too, and this is an important finding: per se high growth is not sufficient to promote worker security. Nevertheless, growth generates many imbalances and social unrest that implicitly at least raise the issue of the implementation of decent work. 
Table 4 - Some developing countries are quite successful in enhancing security

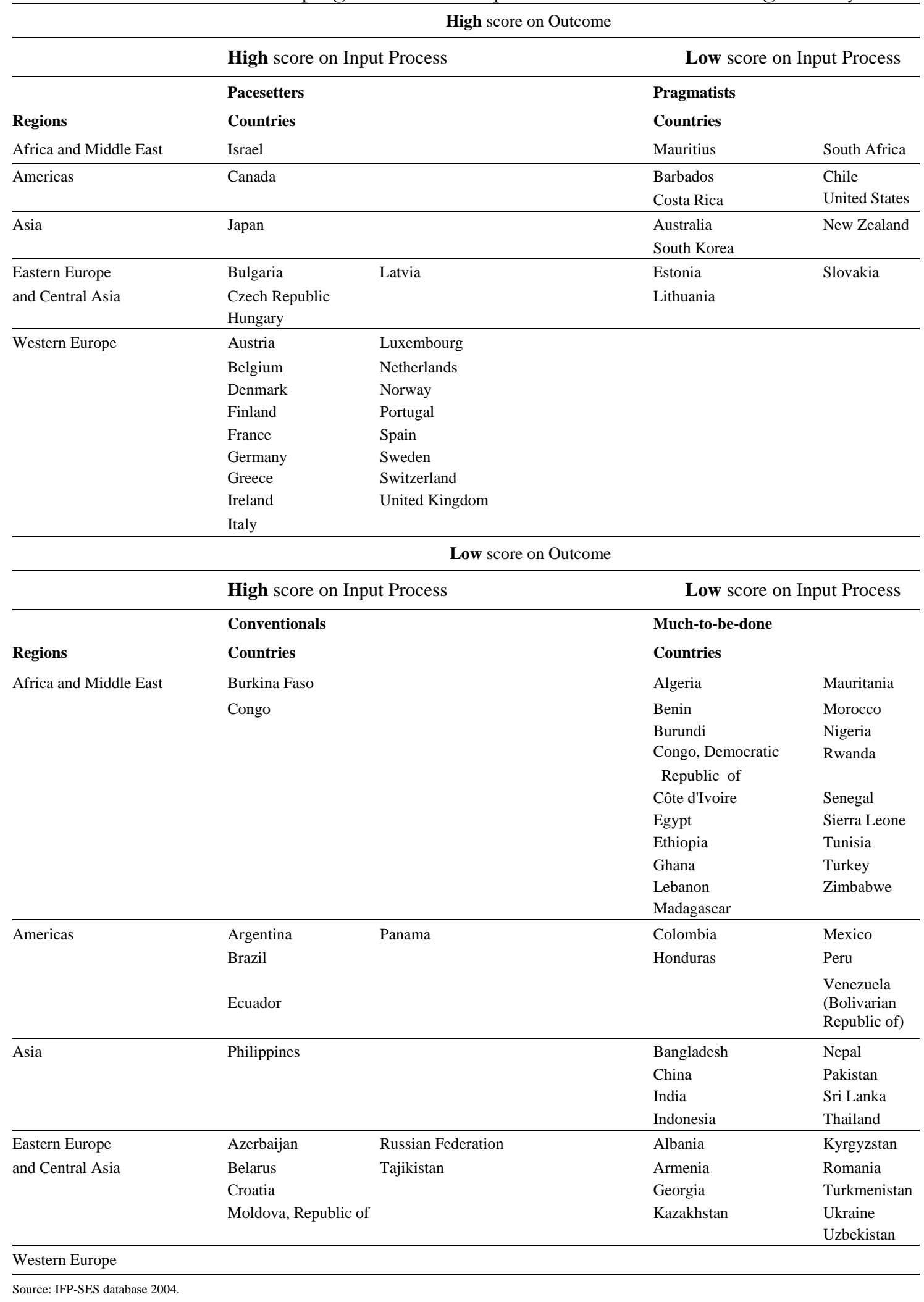

Source: ILO (2004b), p. 277. 


\section{CONCLUSION}

This paper has tentatively challenged the conventional wisdom that the dynamism of employment is always contradictory to the enforcement of some forms of security for workers. Three major arguments can be mobilized.

1. Contemporary theorizing has drastically changed, and economists now recognize the specificity of the wage-labour nexus, by contrast with typical market relations. Consequently, minimum security is required for good economic performance by firms and national economies. Other social sciences do stress the ethical and moral values associated with labour, and thus provide strong justifications for the implementation of basic securities for individuals.

2. A comparative analysis of OECD countries shows that the extended security promoted by welfare systems has not been detrimental to growth, innovation and job creation. On the contrary, small, open social democratic economies display a clear complementarity between security and economic performance, equity and dynamic efficiency. The need for inclusive welfare is clearly perceived by some fast-growing Asian countries, such as South Korea and China.

3. Developing countries cannot immediately catch up with the emerging standards of flexicurity but, quite pragmatically, they should look for the forms of worker security that are compatible with sustainable development. A priori, many different configurations might coexist in response to economic specialization, social values and political choices. 
The epoch of the Washington Consensus is fading away and the idea that "the same size fits all" is probably over. These are clear incentives for a new generation of research, and for innovative policies to sustain the current hope and strategy that has recently emerged in Latin America: "growth with equity".

\section{REFERENCES}

Altman, Roger, Jason Bordoff, Peter Orszag and Robert Rubin (2006). A n E conomic Strategy to A dvance 0 pportunity , Prosperity and G rowth. Washington: Brookings Institution, April.

Amable, Bruno (2003). The D iversity of M odern Capitalisms. Oxford: Oxford University Press.

Aoki, Masahiko (2001). Toward a Comparative Institutional A nalysis. MIT Press, Cambridge, MA.

Atkinson, Anthony B. (1999). The E conomic C onsequenoes of Rolling Back the W elfare State. MIT Press, Cambridge, MA.

Auer, Peter (2005). Protected mobility for employment and decent work: Labor market security in a globalized world. Employment Analysis Research Unit, ILO, Geneva.

Bassanini, Andrea, Stefano Scarpetta and Ignazio Visco (2000). Knowledge, Technology and Economic Growth: Recent Evidence from OECD Countries. Mimeograph, Economics Department, OECD. Prepared for the $150^{\text {th }}$ Anniversary of the National Bank of Belgium: How to Promote Economic Growth in the Euro Area. Brussels, May 11-12.

Bénabou, Rolland (1996). Heterogeneity, stratification, and growth: macroeconomic implications of community structure and school finance. A merican E conomic Review, vol. 86, n 3, p. 584-609.

Bénassy, Jean-Pascal (1982). The E conomics of Mark et D isequilibrium. Academic Press, Boston.

Birdsall, Nancy (2005). Rising Inequality in the N ew G lobal E conomy. Wider Annual Lecture, Wider Angle, $\mathrm{n}^{\circ} 2$, p. 1

Boyer, Robert (ed) (1988). The Search for L abour Flexibility. Clarendon Press, Oxford. 
Boyer, Robert (1992). Labour institutions and economic growth: A survey and a "regulationist" approach. Couverture Orange CEPREMAP, n 9218, November.

Boyer, Robert (1993). The Economics of Job Protection and Emerging New Capital-Labor Relations. In C.H. Buechtemann (ed). E mployment Security and L abor Market Behavior. Cornell University Press, Ithaca: 69-125

Boyer, Robert (1994). Do labour institutions matter for economic development? A "regulation" approach for the OECD and Latin America with an extension to Asia. In Gerry Rodgers (ed). W ork ers, institutions and eonomic growth in A sia. ILO/ILLS, Genève:

$25-112$.

Boyer, Robert (2000). The French Welfare. An institutional and historical analysis in European perspective. Couverture Orange CEPREMAP, n 2000-07.

Boyer, Robert (2004). The F uture of E conomic G rowth. Edward Elgar Publishing, Cheltenham, UK.

Boyer, Robert (2006). La flexicurité danoise. Quels enseignements pour la France. Opuscule CEPREMAP, Editions de l'ENS, Paris, http://www.cepremap.ens.fr/depot/opus/OPUS2.pdf

Boyer, Robert and Jacques Mistral (1982). A coumulation, Inflation, Crises. Presses Universitaires de France, Paris (1 $1^{\text {ère }}$ édition 1978).

Boyer, Robert and Julio-Cesar Neffa (2004). La economia argetina y su crisis (1976-2001). V isiones institutionalistas y regulacionistas. Mino y Davila, Madrid/Buenos Aires.

Cerra, Valerie and Sweta Chanan Saxena (2005). Growth dynamics: the myth of economic recovery. International Monetary Fund: IMF Working Paper No. 05/147.

Chen, Martha Alter (2006). Rethinking Formalisation of the Informal E conomy: W ho, W hat, W hy, and H ow. Prepared for the UN/DESA Development Forum on Productive Employment and Decent Work, held at United Nations Headquarters, New York, on May 8 and 9 2006. 
Chenery, H. and T.N. Srinivasan (eds) (1988). H andbook of development E conomics. Vol. I, Geneva: Elsevier Science Publishers B.V: 40-71.

Council of Economic Advisers (1998). E conomic Report of the President, 1998. Washington DC.

De Soto (1986). El otro sendero. La revolucion informal. Lima, Instituto libertad y Democracia.

Duménil, Gérard and Dominique Lévy(1993). The E conomics of the Profit Rate: Competition, Crises, and H istorical Tendencies in C apitalism. Edward Elgar, Aldershot, England.

Eliasson, Günar (1984). Micro Heterogeneity of Firms and the Stability of Industrial Growth. Journal of E conomic Behavior and O rganization, Vol. 5, N 3-4, pp. 249-274.

Foundation, Albert and Mary Lasker (2000). Ex œptional Returns. Conference on The Economic Value of America's Investment in Medical Research, www.fundingfirst.org

Freeman, Richard B. and D. Medoff (1984). W hat do U nions D 0? Basic Books, New York.

Ghai, Dharam (2002). Decent work: concepts, models and indicators. International Institute for Labor Studies. Discussion Paper No. 139.

Ghose, Ajit K. (2003). Jobs and incmes in a globalizing world. ILO, Geneva.

Guanghua, Wan (2005). Rising Inequality in Post Reform China. Wider Angle, n 2, p. 10.

Guellec, Dominique (2000). Economic Growth in Europe: Entering a New Era. Mimeograph presentation at the D eutsch-Französisches W irtschaftspolitisches Forum, Bonn, 17 and 18 January.

Hausmann, Ricardo, Dani Rodrik and Andrès Velasco (2005). Growth Diagnostics. Mimeograph, John Kennedy School of Government, Harvard University, March.

Heiner, H. (1988). Imperfect Decisions and Routinized Production: Implications for Evolutionary Modeling and Inertial Technical Change. In Giovanni Dosi Christopher Freeman, Richard Nelson, Gerald Silverberg and Luc Soete (eds). Technical Change and E conomic Theory. Pinter Publishers, London.

ILO (2002). D ecent work and the informal economy. International Labour Conference, $90^{\text {th }}$ session.

ILO (2004a). W orld E mployment Report, 2004-2005. International Labour Office, Geneva. 
ILO (2004b). E conomic security for a better world. International Labour Office, Geneva.

Kalantzis (2006). Structure sectorielle et fragilité financiers dans les économies émergentes. Thèse EHESS, Paris.

Katzenstein, Peter J. (1985). Small States in W orld Mark ets: Industrial Policy in E urope. Ithaca: Cornell University Press.

Kucera, David (2001). The effects of core workers' rights on labour costs and foreign direct investment: Evaluating the conventional wisdom. International Institute for Labour Studies. Discussion Paper No. 130/2001, Geneva.

Kwon, Huck-Ju (2006). Transforming the Development Welfare States in East Asia. Mimeograph, Sung Kyun Kwan University, Seoul.

Levis, Julien (2006). Adoption of corporate social responsibility codes by multinational companies. Journal of A sian E conomics, 17(1), February: 50-55.

Lobel, Orly (2006). Sustainable capitalism or ethical transnationalism: Offshore production and economic development. Journal of A sian E conomics, 17(1), February: pp. 56-62.

Lucas, Robert (1988). On the Mechanisms of Economic Development. Journal of Monetary E onomics, Vol. 72, July: 3-42.

Lucas, Robert (1993). Making a Miracle. E conometrica 61(2): 251-272.

Nkurunziza, Janvier (2006). Generating rural Employment in Africa to Tight Poverty. Paper prepared for the High-Level Segment of the Economic and Social Council.

OECD (1999). The Knowledge Based E conomy: A set of acts and figures. OECD Publication, Paris.

Pagès, Carmen (2003). Good Jobs W anted: Labor Markets in Latin A merica, Inter-American Development Bank, Washington DC, October.

Prasad, Eswar, Kenneth Rogoff, Shang-Jin Wei and Ayhan Kose (2004). Financial Globalization, Growth and Volatility in Developing Countries. NBER Working Paper No. 0942, Cambridge, MA. 
Stone, Katherine V.W. (2005). Flexibilization, Globalization, and Privitization: Three Challenges to Labour Rights in Our Time. G lobalization and L abor standards (G A L S). Working Paper Series, 1-05. UCLA School of Law, University of California, Los Angeles.

Tachibanaki, Toshiaki (2000). Japan Was Not A Welfare State, But... In Griffiths, Richard T. and Toshiaki Tachibanaki. From A usterity of A ffluenœ: The transformation of the Socio-E onomic Structures of W estern E urope and Japan. London: MacMillan Press, Chapter 11: 188-208.

Tachibanaki, Toshiaki, Hiroshi Fujiki and Sachiko Kuroda Nakada (2000). Structural Issues in the Japanese Labor Market. An era of variety, equity and efficiency or an era of bipolarization? IMES Discussion Paper, Series 2000-E-X, August.

Todaro, Michael P. and Stephen C. Smith (2005). E conomic D evelopment (Ninth edition). Pearson Education Limited, Harlow, UK.

Tokman, Victor (2006). Integrating the informal sector in the modernization process. Prepared for the UN/DESA Development Forum on Productive Employment and Decent Work, held at United Nations Headquarters, New York, on May 8 and 92006.

Touffut, Jean-Philippe (1999). Stabilité, transformation et émergenœ des modes de coordination dans la Russie post-soviétique. Thèse EHESS, Paris, et Université Lomonosov de Moscou, Octobre.

Vijayabaskar, M. (2005). Governance of flexible accumulation in clusters: can it create "decent work" in low income region. Mimeograph, Madras Institute of Development Studies.

Waisgrais, Sebastian (2002). Desigualdad salarial y Mercado del trabajo en Argentina. 1980-1999. Instituto International de Estudios Labourales, Ginebra.

World Health Organization (2000). A nnual report, Oxford, Oxford University Press. 